El giro performativo en las artes visuales

A propósito de cuerpos, espacios y objetos puestos en acto

Silvina Valesini, Guillermina Valent

Arte e Investigación (N. ${ }^{\circ} 17$ ), e052, mayo 2020. ISSN 2469-1488

https://doi.org/10.24215/24691488e052

http://papelcosido.fba.unlp.edu.ar/ojs/index.php/aei

Facultad de Artes. Universidad Nacional de La Plata

La Plata. Buenos Aires. Argentina

\title{
EL GIRO PERFORMATIVO EN LAS ARTES VISUALES A PROPÓSITO DE CUERPOS, ESPACIOS Y OBIETOS PUESTOS EN ACTO
}

\author{
THE PERFORMATIVE TURN IN VISUAL ARTS \\ ABOUT BODIES, SPACES AND OBJECTS PUT INTO ACTION
}

\author{
SILVINA VALESINI / silvinavalesini@fba.unlp.edu.ar \\ GUILLERMINA VALENT / guillerminavalent@gmail.com \\ Instituto de Investigación en Producción y Enseñanza del Arte Argentino y Latinoamericano. \\ Facultad de Artes. Universidad Nacional de La Plata. Argentina
}

Recibido 19/2/2020 I Aceptado 11/4/2020

\section{RESUMEN}

El proyecto se propone problematizar el campo de las artes visuales a la luz de su giro performativo, un enfoque que se caracteriza por la asimilación de recursos y estrategias vinculadas a las artes escénicas, en su actualización del concepto de teatralidad. De esta manera, la presencia de los cuerpos y de la acción como gesto significativo opera tensionando el concepto de representación. Así, la obra entendida como proceso extiende y complejiza sus alcances tanto en las condiciones de producción como en instancias de recepción. Se trata de una investigación exploratoria-interpretativa donde considerar la complejidad del fenómeno nos invita a proponer un abordaje transdisciplinario, que compromete el trabajo de cátedras de diferentes carreras de la Facultad de Artes de la Universidad Nacional de La Plata.

\section{PALABRAS CLAVE}

Giro performativo; artes visuales; acción; teatralidad; experiencia

\section{ABSTRACT}

The present project proposes to problematize the field of visual arts in the light of its performative turn, an approach characterized by the assimilation of resources and strategies related to the performing arts, in its updating of the concept of theatricality. In this way, the presence of bodies and action as a significant gesture operate by tensing the concept of representation. Thus, the work conceived as a process extends and complicates its scope both in the production conditions and in the reception instances. It is an exploratory-interpretive research, where considering the complexity of the phenomenon invites us to propose a transdisciplinary approach, which compromises the work of the chairs of different careers at the UNLP Faculty of Arts.

\section{KEYWORDS}

Performative turn; visual arts; action; theatricality; experience 


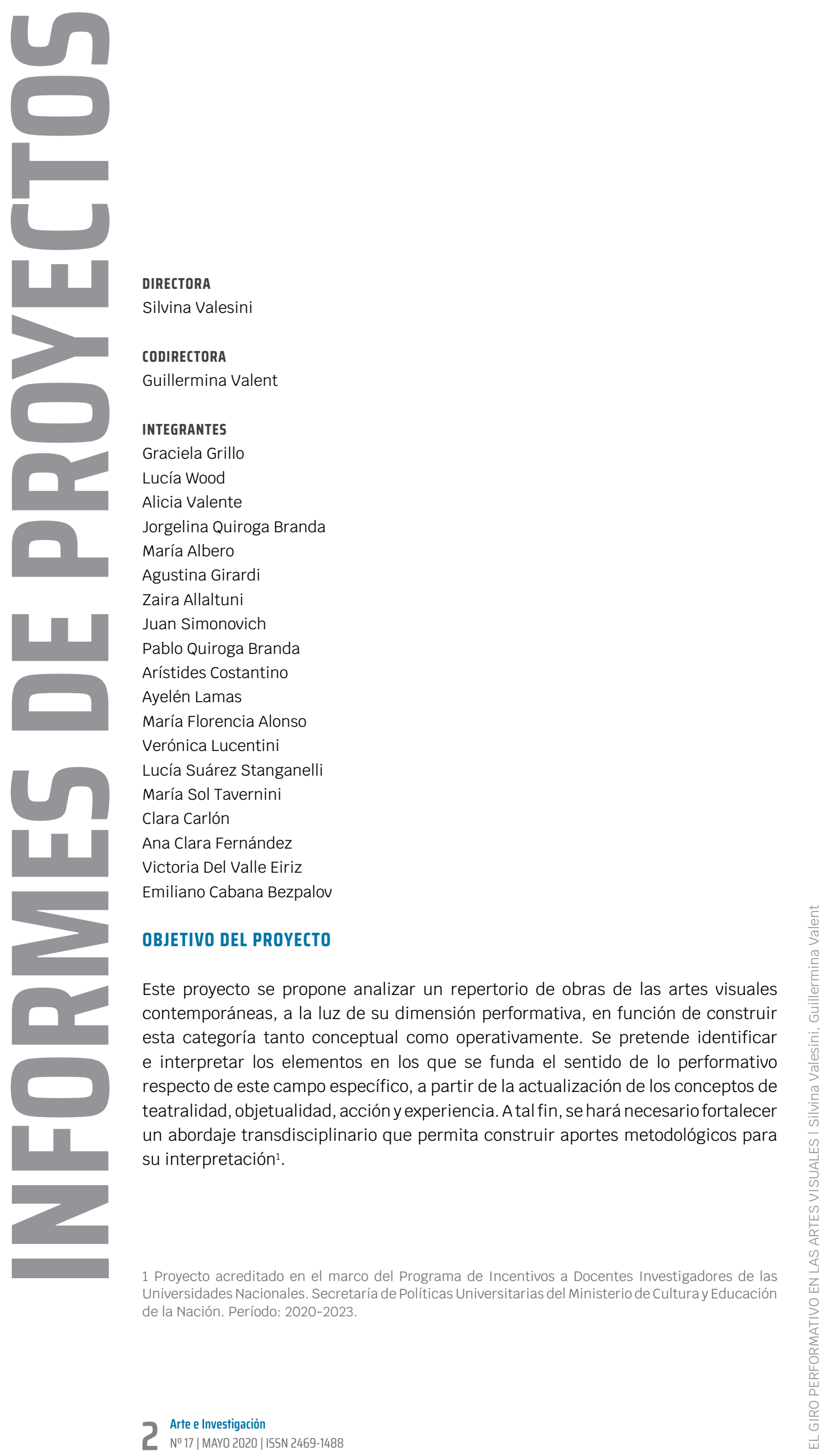




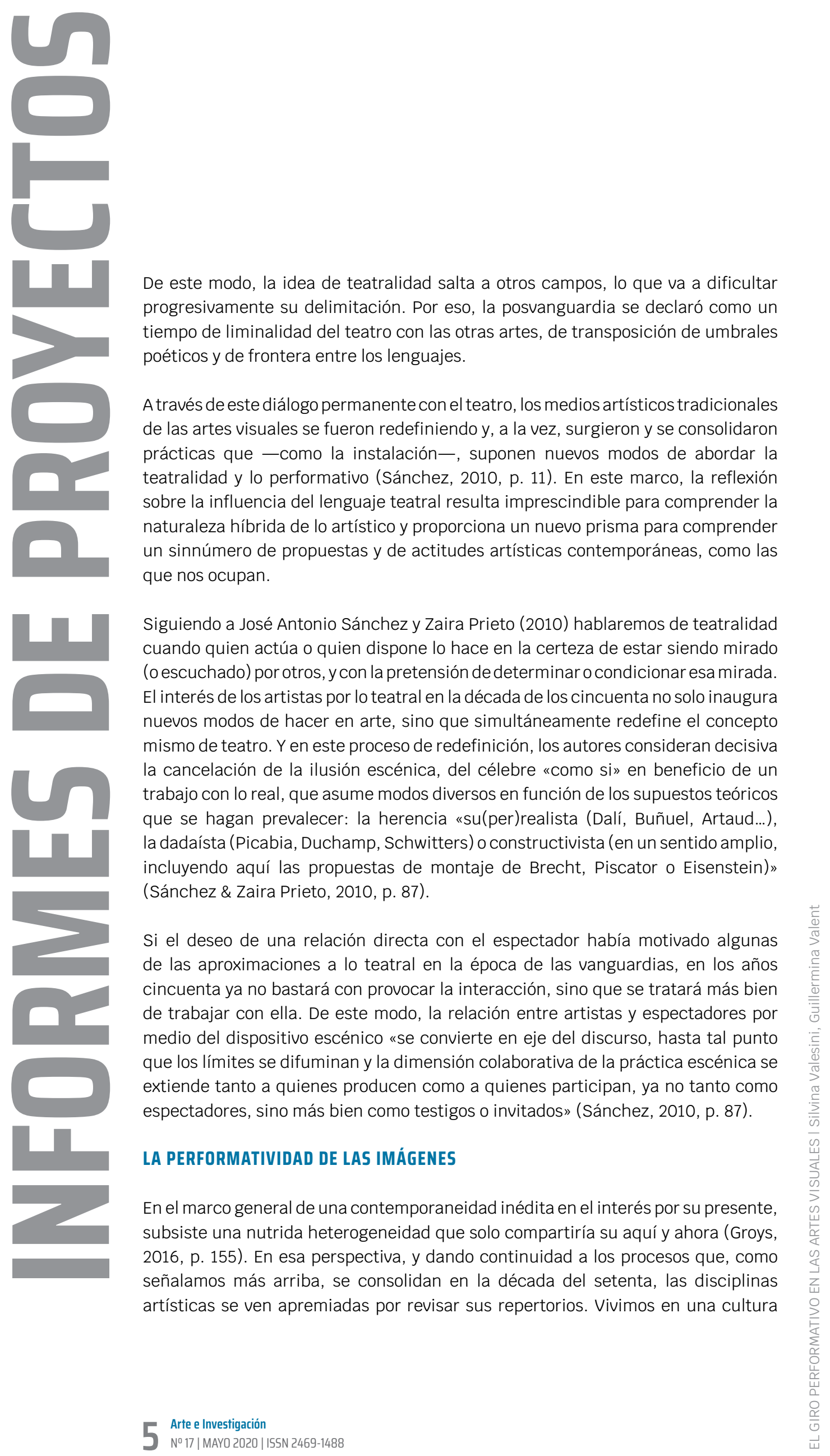




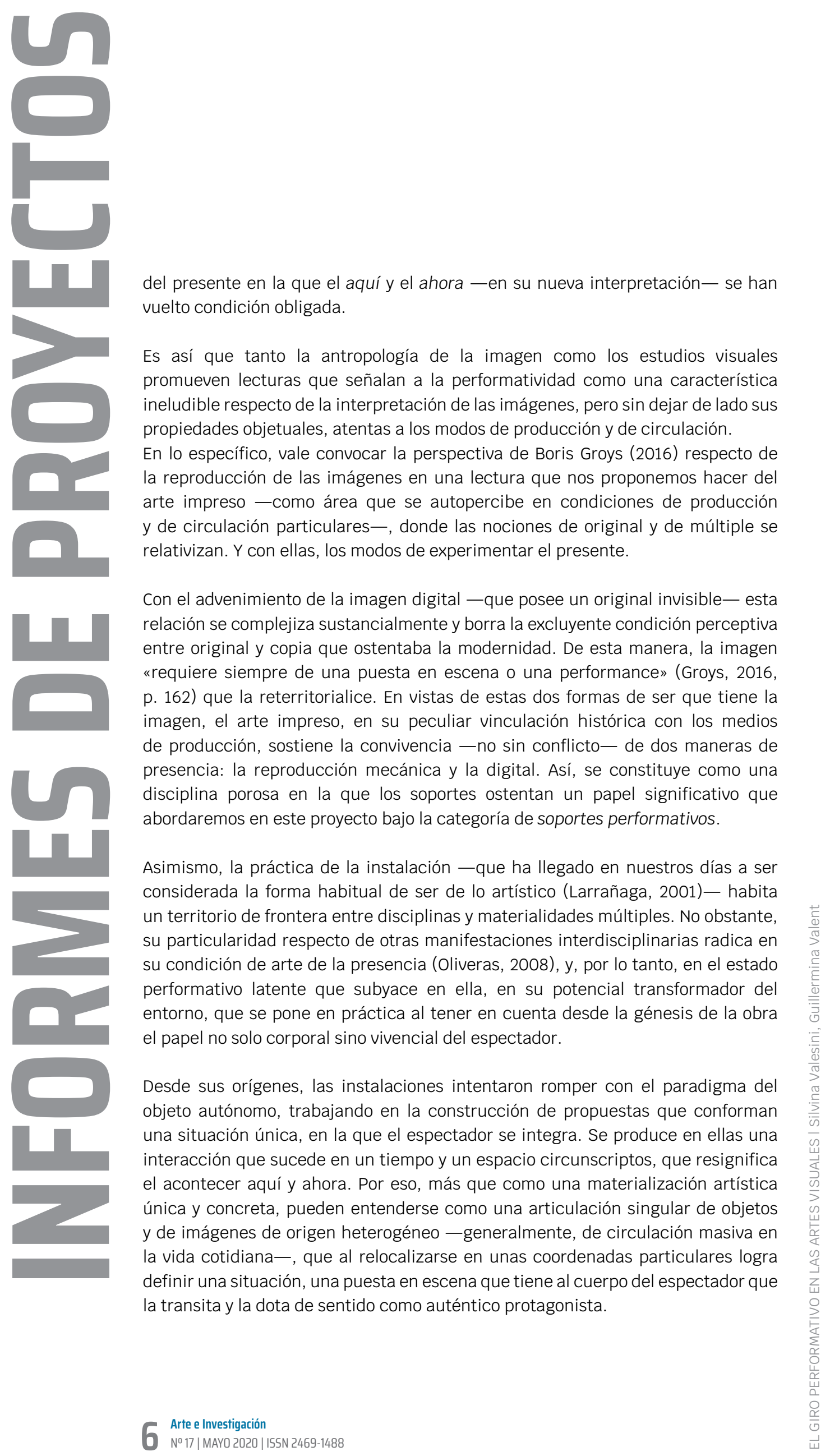




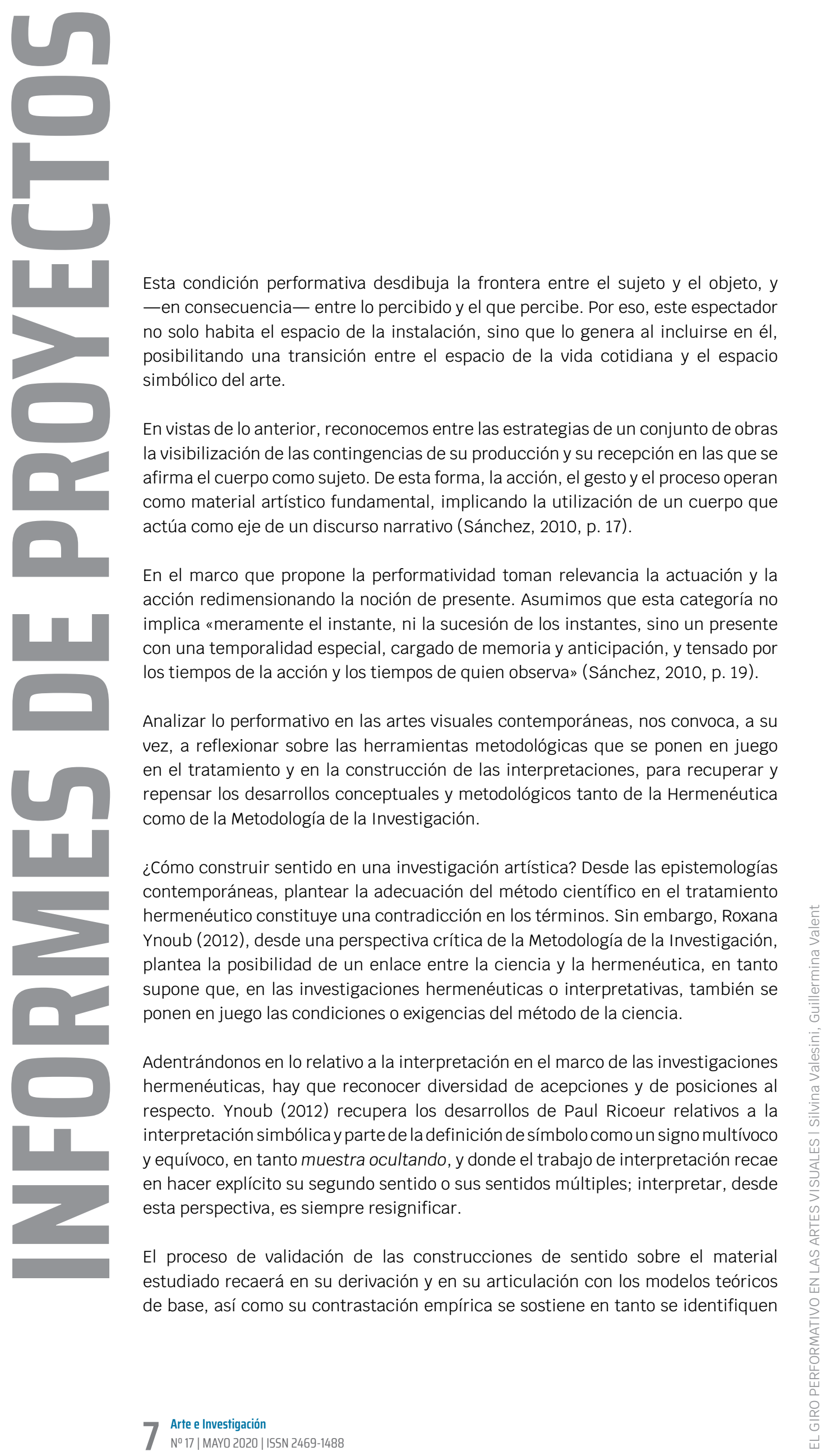




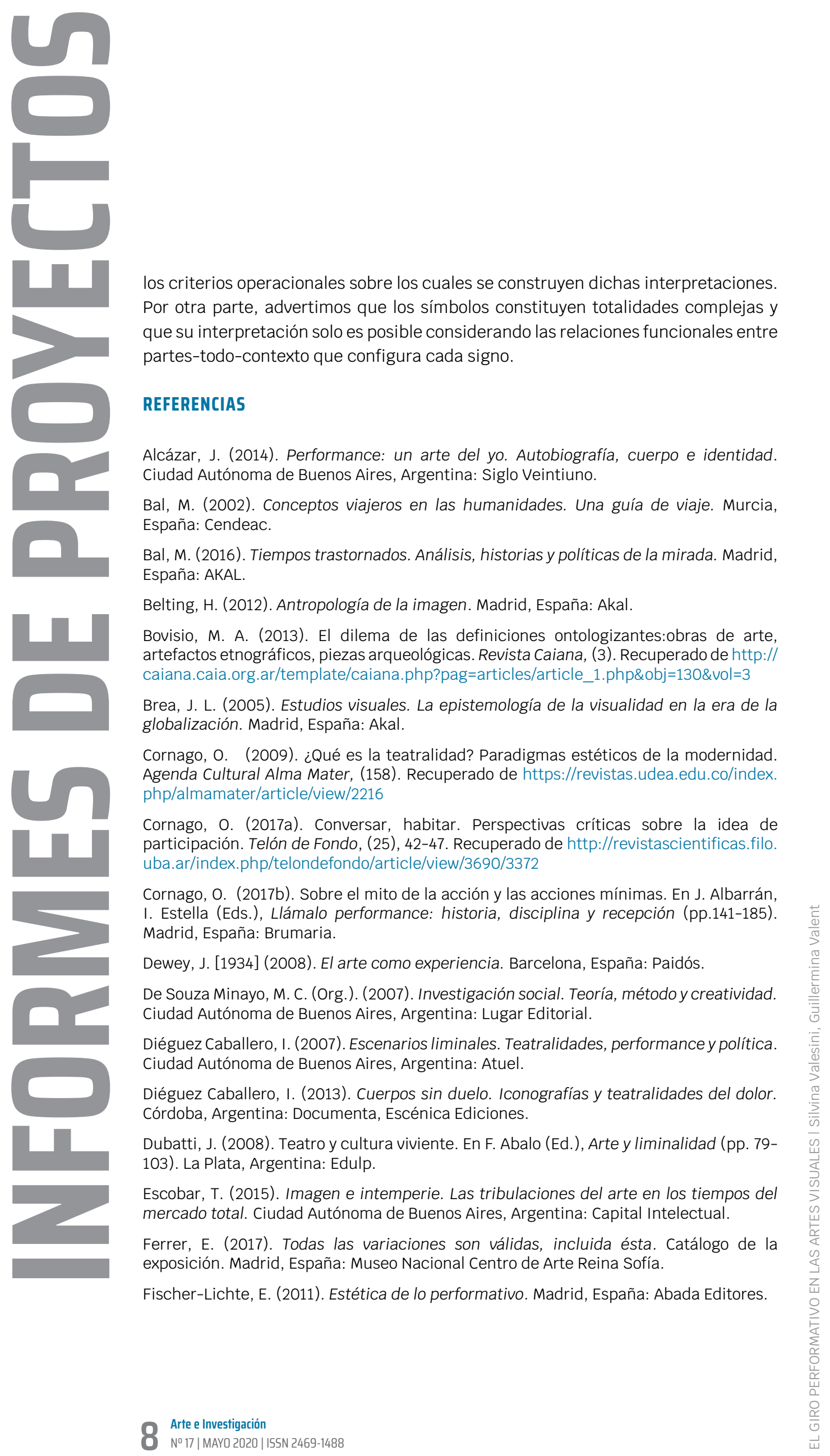




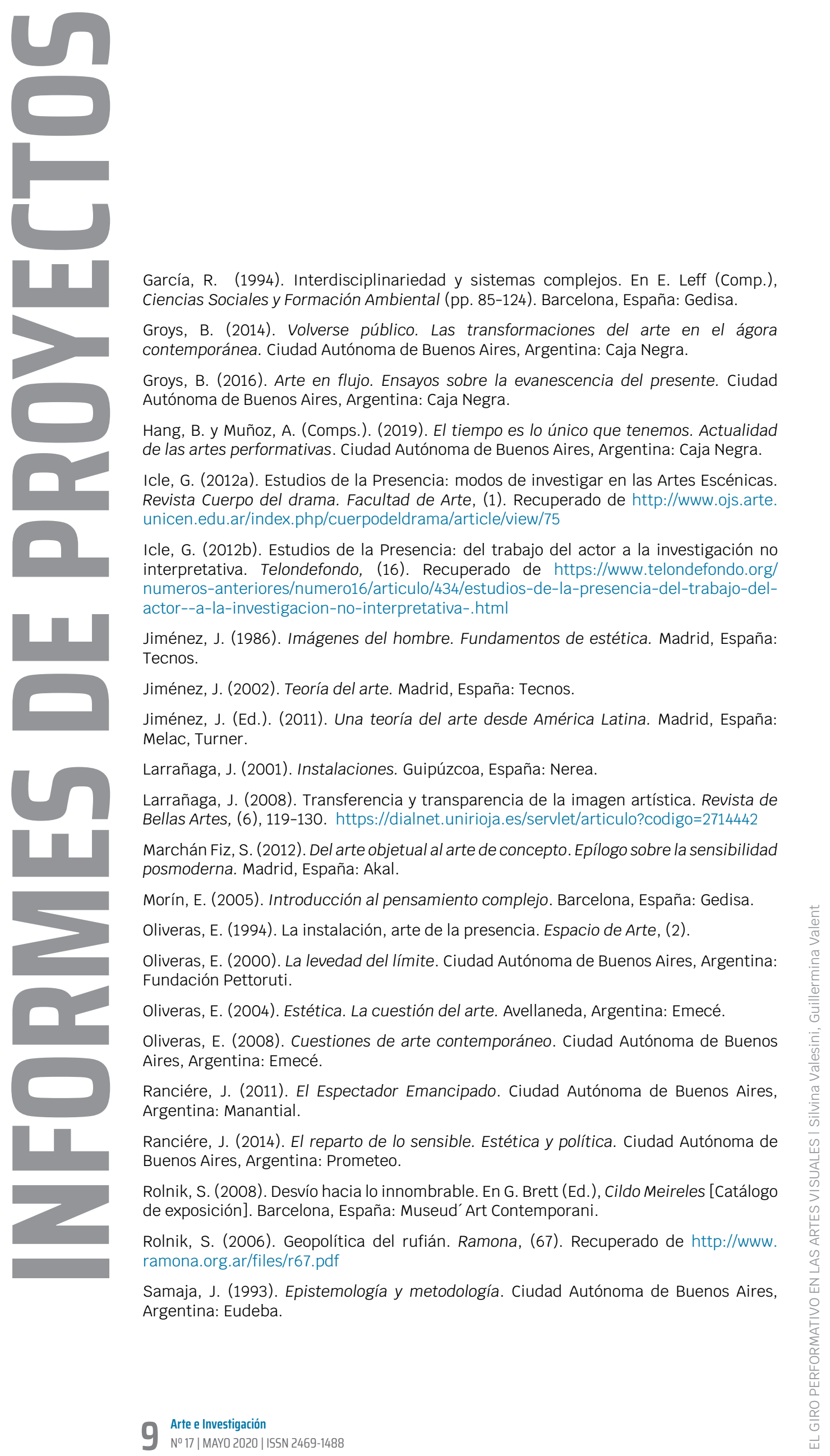


